\title{
Regulation of hrp Genes and Type III Protein Secretion in Erwinia amylovora by HrpX/HrpY, a Novel Two-Component System, and HrpS
}

\author{
Zhongmin Wei, Jihyun F. Kim, and Steven V. Beer \\ Department of Plant Pathology, Cornell University, Ithaca, NY 14853, U.S.A. \\ Accepted 12 June 2000.
}

Two novel regulatory components, $h r p X$ and $h r p Y$, of the hrp system of Erwinia amylovora were identified. The $h r p X Y$ operon is expressed in rich media, but its transcription is increased threefold by low $\mathrm{pH}$, nutrient, and temperature levels-conditions that mimic the plant apoplast. $h r p X Y$ is autoregulated and directs the expression of $h r p L$; $h r p L$, in turn, activates transcription of other loci in the hrp gene cluster (Z.-M. Wei and S. V. Beer, J. Bacteriol. 177:6201-6210, 1995). The deduced amino -acid sequences of $h r p X$ and $h r p Y$ are similar to bacterial two-component regulators including VsrA/VsrD of Pseudomonas (Ralstonia) solanacearum, DegS/DegU of Bacillus subtilis, and UhpB/UhpA and NarX/NarP, NarL of Escherichia coli. The N-terminal signal-input domain of HrpX contains PAS domain repeats. hrpS, located downstream of $h r p X Y$, encodes a protein with homology to WtsA (HrpS) of Erwinia (Pantoea) stewartii, HrpR and HrpS of Pseudomonas syringae, and other $\sigma^{54}$-dependent, enhancerbinding proteins. Transcription of $h r p S$ also is induced under conditions that mimic the plant apoplast. However, $h r p S$ is not autoregulated, and its expression is not affected by $h r p X Y$. When $h r p S$ or $h r p L$ were provided on multicopy plasmids, both $h r p X$ and $h r p Y$ mutants recovered the ability to elicit the hypersensitive reaction in tobacco. This confirms that $h r p S$ and $h r p L$ are not epistatic to $h r p X Y$. A model of the regulatory cascades leading to the induction of the $E$. amylovora type III system is proposed.

Additional keywords: fire blight, pathogenicity, virulence.

Erwinia amylovora is the causal agent of the fire blight disease of many rosaceous plants including pear and apple (van der Zwet and Beer 1999). The bacterium infects blossoms, leaves, succulent shoots, and immature fruits. Symptoms of the infected plants include water soaking and discoloration,

Corresponding author: S. V. Beer; Telephone: +1-607-255-7870; Fax: +1-607-255-4471; E-mail: svb1@ cornell.edu

Current address of Zhongmin Wei: EDEN Bioscience Corp., 11816 North Creek Parkway, Bothell, WA 98011-8205, U.S.A.

J. F. Kim and Z. Wei contributed equally to the work and should be considered co-first authors.

Nucleotide and/or amino acid sequence data have been deposited in the GenBank data base under accession number AF083877. followed by necrosis. Sometimes the disease kills whole trees or substantial portions, resulting in devastating economic loss. In nonhost plants such as tobacco and Arabidopsis, the bacterium elicits the defensive hypersensitive reaction (HR), which is characterized by rapid, localized, cell death (Goodman and Novacky 1994). For infection and HR induction, genes generally called $h r p$ (hypersensitive response and pathogenicity; see Alfano and Collmer 1996 for a review) are essential.

The hrp gene cluster of E. amylovora Ea321 has been cloned in several cosmids and enables nonpathogenic bacteria such as Escherichia coli to elicit the HR in plants (Beer et al. 1991). According to phenotypic analyses of mutants, hrp genes of E. amylovora are localized within a $25-\mathrm{kb}$ region of DNA, consisting of at least eight transcriptional units (Wei and Beer 1993). Sequence analysis (Bogdanove et al. 1996; Kim et al. 1997) indicated that the majority of hrp genes encode proteins that are thought to be components of a specialized protein secretion apparatus called the type III pathway (Hrp pathway for plant pathogens) (Galán and Bliska 1996). Several proteins including harpins ( $\mathrm{HrpN}$ and $\mathrm{HrpW})$ and a pathogenicity/avirulence protein (DspE) have been shown to be secreted via the pathway (Bogdanove et al. 1998a; Kim and Beer 1998; Wei and Beer 1993).

Transcriptional expression of $h r p$ genes is induced under conditions similar to the environment of the plant apoplast: low carbon and nitrogen, low $\mathrm{pH}$ (5.5), and low temperature $\left(18^{\circ} \mathrm{C}\right)$ (Wei et al. 1992). Two independent loci, complementation groups IV and V, in the hrp cluster were found to have regulatory function (Sneath et al. 1990; Wei and Beer 1993, 1995). Mutations in these loci abolish harpin production and the HR-eliciting and disease-causing abilities of E. amylovora (Wei and Beer 1993). Preliminary sequence analysis indicated that one of them (group IV) contains a gene called hrpS (Sneath et al. 1990) that encodes a protein similar to $\sigma^{54}$ dependent transcriptional activators (Morett and Segovia 1993). Complementation group V encodes hrpL (Wei and Beer 1995), which is homologous to genes encoding members of the ECF subfamily of eubacterial sigma factors (Lonetto et al. 1994). HrpL recognizes conserved promoter sequences called "hrp boxes" (Xiao and Hutcheson 1994), and directs the transcription of other pathogenicity genes including hrp secretion operons ( $h r p A$, hrpC, and $h r p J$ ) (Wei and Beer 1995), harpin genes ( $h r p N$ and $h r p W$ ) (Kim and Beer 1998; Wei and Beer 1995), and a disease-specific locus (dspEF [Bogdanove et al. 1998b]; $d s p A B$ [Gaudriault et al. 1997]). 
Here we report the characterization of two new regulatory genes, designated $h r p X$ and $h r p Y$, and the further analysis of $h r p S$. $h r p X$ and $h r p Y$ are present in an operon situated between $h r p S$ and $h r p L$. Analysis of deduced protein sequences suggested that they constitute a two-component regulatory complex; HrpX functioning as a sensor and HrpY as the responseregulator partner of HrpX. $h r p X, h r p Y$, and $h r p S$ are components of a complex regulatory network that leads to activation of $h r p L$ and eventually other genes in the hrp cluster of $E$. amylovora.

\section{RESULTS}

Identification and sequence analysis of the $h r p X Y$ locus.

Previous studies have identified several loci, including $h r p C, h r p A, h r p S, h r p L$, and $h r p J$, that are essential for the Hrp phenotype (Bogdanove et al. 1996; Kim et al. 1997; Wei and Beer 1993, 1995) (Fig. 1A). Preliminary genetic analysis of pCPP430 in Escherichia coli suggested the presence of a new locus, between $h r p S$ and $h r p L$, that also is required for the Hrp phenotype and contains novel regulatory components. We have designated this locus $h r p X Y$.

A 3.4-kb BglII- and ClaI-digested fragment of pCPP430 was cloned into pBluescript $\mathrm{KS}+$, resulting in pCPP1178. The sequence of the insert of pCPP1178 revealed two tightly linked open reading frames (ORFs) between $h r p L$ and $h r p S$ that are capable of encoding proteins of 495 and 213 amino acid residues, respectively (Fig. 1B). These ORFs were named $h r p X$ and $h r p Y$, respectively. Potential ribosome-binding sites, AGGAG and TGGAA, were found 5 and $7 \mathrm{bp}$ upstream of the $h r p X$ and $h r p Y$ start codons, respectively. Although the ribosome-binding site ahead of $h r p Y$ weakly matches the consensus sequence, we assume it is sufficient for translation of $h r p Y$; only a 4-bp space exists between the $h r p X$ stop codon and $h r p Y$ start codon and translational coupling is plausible. To confirm that the $h r p X$ and $h r p Y$ ORFs produce proteins, pCPP1178 was placed in a gene expression system mediated by the T7 RNA polymerase. Two distinct protein bands were visible following sodium dodecyl sulfate-polyacrylamide gel electrophoresis (SDS-PAGE). The apparent molecular masses of HrpX and HrpY were about 50 and $25 \mathrm{kDa}$, respectively (data not shown), close to the sizes expected from the deduced amino acid sequences.

The start codon of $h r p X$ is located 146 bp downstream of the $h r p L$ stop codon, and a promoter prediction program (see Materials and Methods) identified two putative $\sigma^{70}$ promoter sequences, TAGACG-N ${ }_{17}$-TAAAGT (score from promoter prediction by neural network $=0.97$ ) and TTGCAA- $\mathrm{N}_{16}$-CCTAAT (score $=0.95), 111$ and $33 \mathrm{bp}$ upstream of the $h r p X$ start codon, respectively. There is a 361-bp noncoding region between $h r p Y$ and $h r p S$. Palindromic sequences that may serve either as targets of regulatory components or as transcription terminators, GTAAACANTGTTTAC and GGATAAAATGGTTGTGG-N ${ }_{7}$-CCGCTTCCATTTTATCC, were identified in the $h r p L-h r p X$ and $h r p Y$ - $h r p S$ intergenic regions, respectively. The tight linkage of $h r p X$ and $h r p Y$, and the existence of long noncoding areas and inverted repeats upstream of $h r p X$ and downstream of $h r p Y$, suggest that the two genes form an operon.

\section{HrpX and HrpY constitute}

a two-component regulatory system.

Comparison of the predicted amino acid sequences of $h r p X$ and $h r p Y$ with sequences in the data bases revealed significant similarities with many two-component regulatory proteins. The homologs include VsrA/VsrD of Pseudomonas (now Ralstonia) solanacearum, which regulate virulence gene expression (Huang et al. 1995b); UhpB/UhpA of Escherichia coli, which participate in the regulation of sugar transport (Friedrich and Kadner 1987); NarX/NarP,NarL of Escherichia

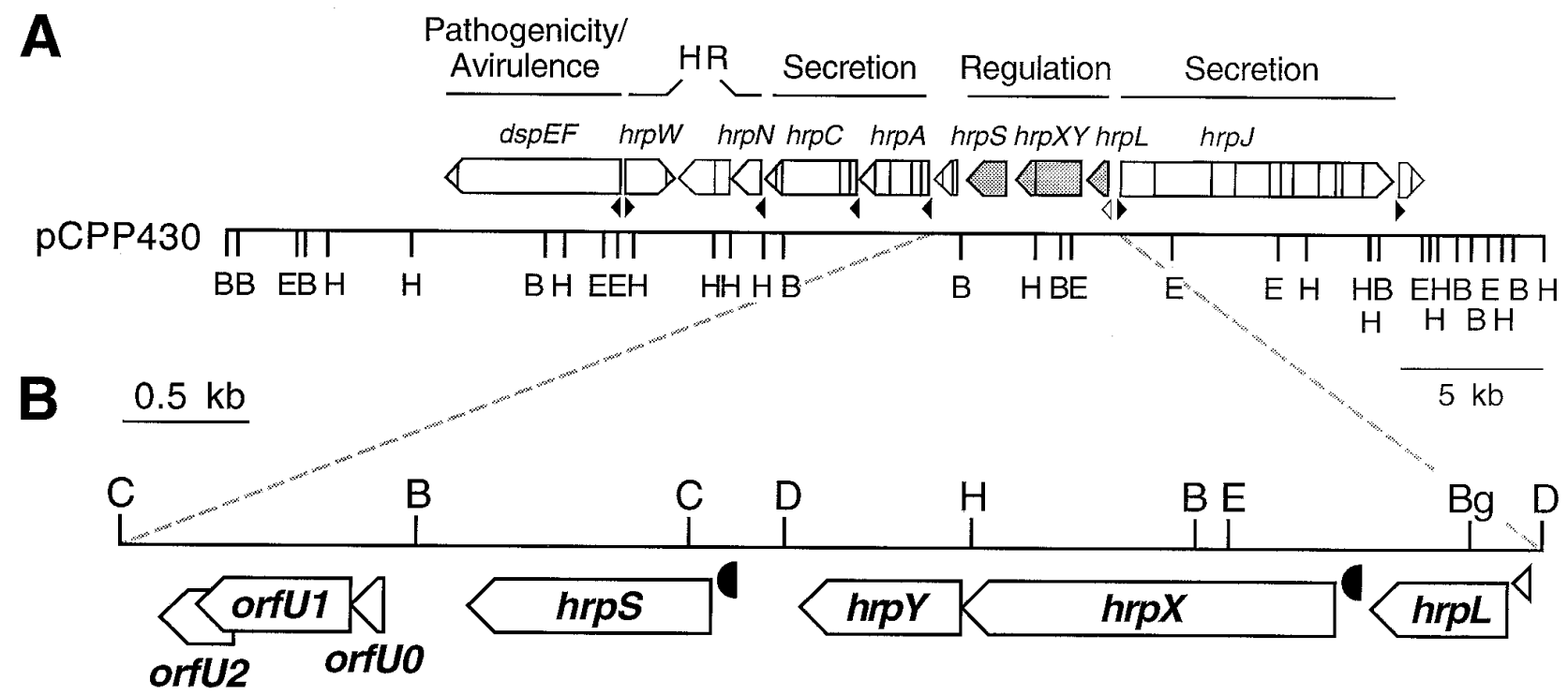

Fig. 1. A, Operon organization of the hrp/dsp gene cluster of Erwinia amylovora cloned in pCPP430. B, Central region covering regulatory genes hrpL, hrpX, hrpY, and hrpS. Boxes and arrow boxes: transcriptional units or open reading frames; names of the characterized operons or genes are given above, inside, or below. Filled triangles: putative HrpL-dependent promoters. Open triangles: putative $\sigma^{54}$ promoters. Closed half circles: putative $\sigma^{70}$ promoters. Restriction enzymes: B, BamHI; E, EcoRI; H, HindIII; Bg, BglII; C, ClaI; and D, DraI. 
coli, which are involved in the regulation of anaerobic respiratory gene expression (Rabin and Stewart 1993); and DegS/DegU of Bacillus subtilis, which are involved in extracellular enzyme production (Kunst et al. 1988) (Fig. 2; Table 1). In addition, HrpY showed high sequence similarity with many other transcriptional activators including ExpA of $E$. carotovora (33\% identity), which is involved in global control of virulence (Eriksson et al. 1998); UvrY of Escherichia coli (33\% identity) (Sharma et al. 1986); SirA of Salmonella typhimurium (32\% identity) (Johnston et al. 1996); and GacA of several animal- and plant-associated Pseudomonas spp. (29 to $30 \%$ identities) (Laville et al. 1992).

The high sequence similarity of HrpX with histidine kinases suggests that HrpX is a sensor. HrpX has the conserved His

A

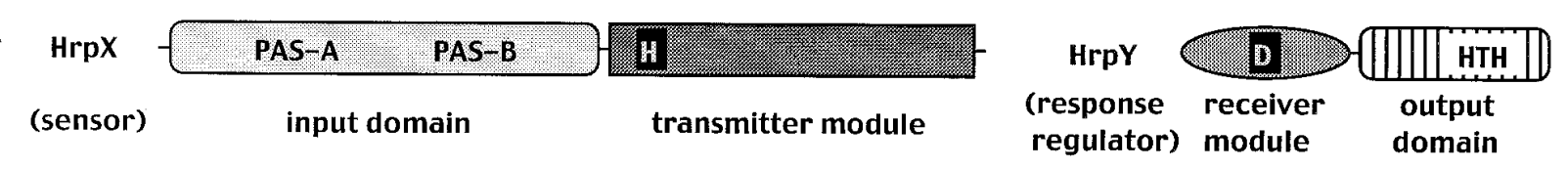

B

$\operatorname{HrpX}$-Eam

Nifl-Avi

HroX-Eam

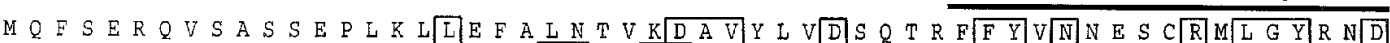

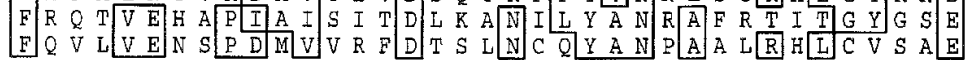

HroX-Eam NifL-Avi

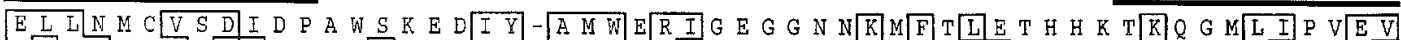

HrpX-Eam

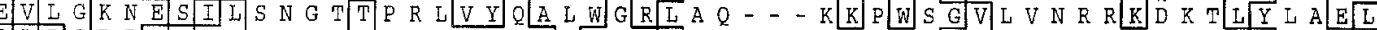

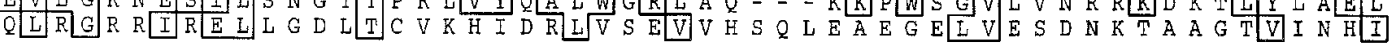
$\mathrm{S}_{2}$

TKP

HrpX-Eam

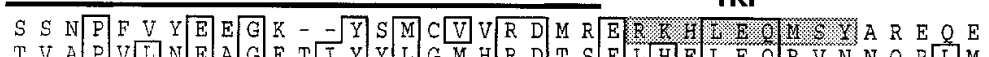

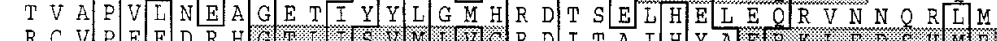

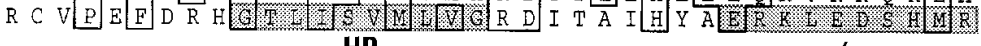

HP

$\mathbf{P}$

$+/-$

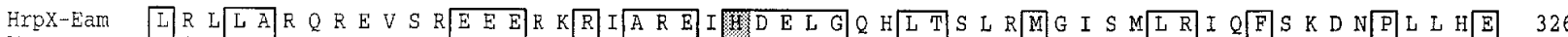

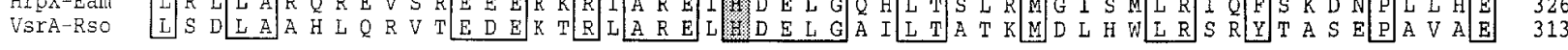

HrpX-Eâm R V V H L L M G L T

Vsra-Rso KLI T R V V M A H V V D Q

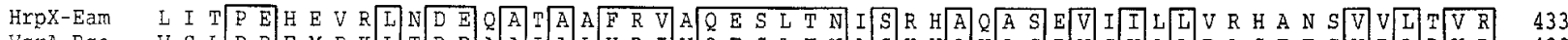

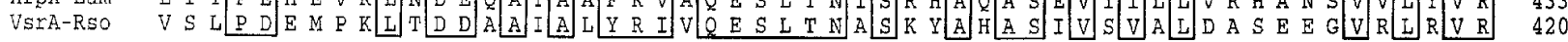

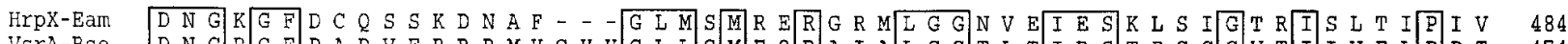
VsrA-RSO D N G R R F P A D V E R R R M V G H H G L L G M E Q

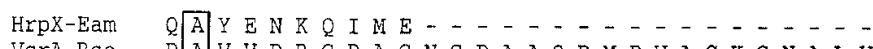

Vsra-Rso DA.VVDRGD A GNG P A A D M P V A G K GN A L V

C

HLHd

VsrD-Rso

GacA-Pf1

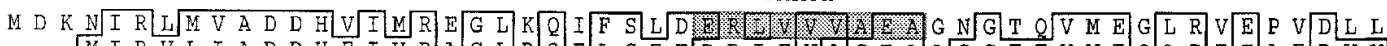

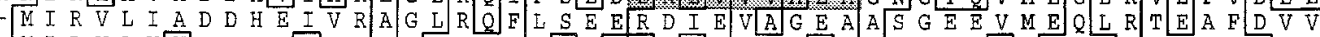

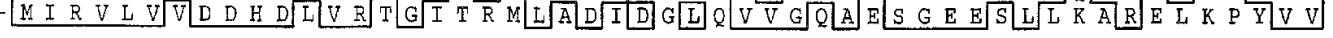

$\mathbf{P}$

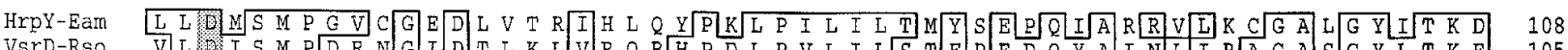

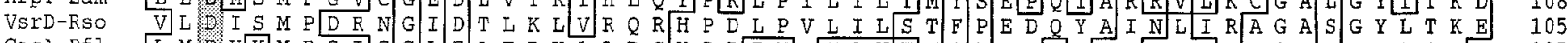

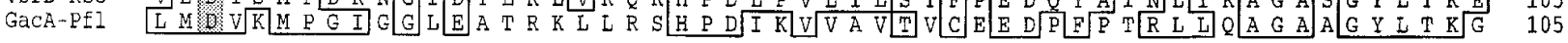

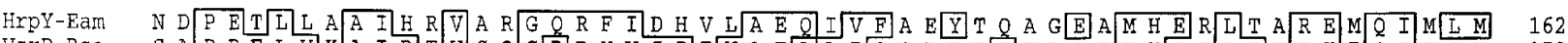

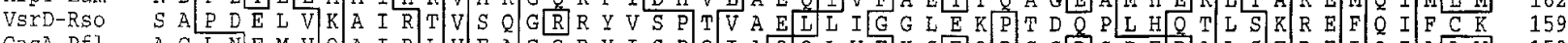

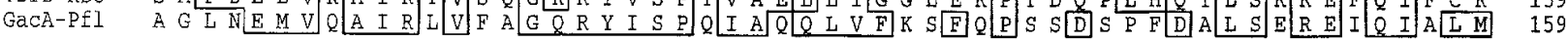
HTH

HrpY-Eam

VsrD-Rso

GacA-Pf1

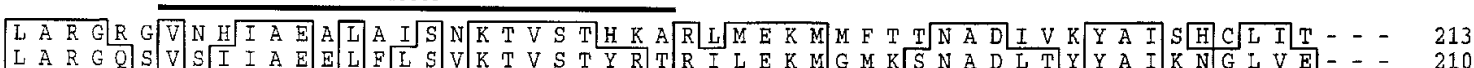

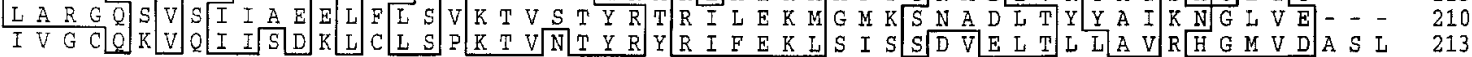

Fig. 2. A, Diagramatic illustrations of HrpX and HrpY of Erwinia amylovora showing predicted domain structures. B and C, Alignment of HrpX and HrpY with similar proteins. Designations of diagrams are after Parkinson and Kofoid (1992). PAS-A and PAS-B denote two repeats of the PAS domain, $\mathrm{H}$ and D phosphorylated histidine and aspartate residues, respectively, and HTH the helix-turn-helix DNA-binding motif. Overlines represent the Sboxes in the PAS domain $\left(\mathrm{S}_{1}\right.$ and $\left.\mathrm{S}_{2}\right)$ and the HTH motif. A putative tyrosine kinase phosphorylation site (TKP), a hydrophobic region (HP), a putative charge-rich linker (+/-), and a helix-loop-helix dimerization domain signature (HLHd), and phosphorylation sites (P) are shown by shading. PILEUP program (GCG software package, vers. 7.3; Genetics Computer Group, Madison, WI, U.S.A.) with default parameters was used to align the sequences. Accession numbers of the compared proteins: NifL of Azotobacter vinelandii, SWISS-PROT:P30663; VsrA and VsrD of Ralstonia solanacearum, PIR:S41544 and PIR:I40540; and GacA of Pseudomonas fluorescens, SWISS-PROT:P32967. In the HrpX alignment, only 27 to 152 residues of NifL and C-terminal 243 residues of VsrA are shown. Also, the HrpX sequence is shown on two lines for the first three rows. 
residue for autophosphorylation and a hydrophobic domain that may enable the protein to be transiently associated with the cytoplasmic membrane (Fig. 2B). The C-terminal putative transmitter domain (residues 273 to 494) of HrpX shows most similarity to the kinase domains of the sensor proteins listed in Table 1; the N-terminal putative input domain of HrpX shows similarity to PAS domains (Zhulin et al. 1997) of Methanobacterium thermoautotrophicum, Azotobacter vinelandii, and other organisms. Several PAS-containing proteins are sensors of bacterial two-component systems. The PAS domain typically consists of two direct sequence repeats (PAS-A and PAS-B), and each repeat contains two highly conserved regions called $S_{1}$ and $S_{2}$ boxes (Zhulin et al. 1997). In the case of HrpX, the second repeat (PAS-B) seems imperfect (Fig. 2B). Based on ScanProsite analysis (Appel et al. 1994), another feature of HrpX with unknown functional relevance is a putative tyrosine kinase phosphorylation site (PROSITE:PS00007).

HrpY appears to be a response regulator with a putative receiver domain at the $\mathrm{N}$ terminus (up to 102 amino acid residues) and a DNA-binding domain at the $\mathrm{C}$ terminus (Fig. 2A). As shown in Figure 2C, HrpY contains the conserved Asp residue, which may be phosphorylated by the sensor, and the

Table 1. HrpX and HrpY of Erwinia amylovora compared with twocomponent regulatory proteins (sensors/response regulators) of other bacteria

\begin{tabular}{llll}
\hline Bacterium & \multicolumn{1}{c}{ Protein } & Amino acids & \% Identity \\
\hline Erwinia amylovora & HrpX/HrpY & $494 / 213$ & - \\
Ralstonia solanacearum & VsrA/VsrD & $502 / 210$ & $34 / 41$ \\
Escherichia coli & UhpB/UhpA & $500 / 196$ & $32 / 32$ \\
Bacillus subtilis & DegS/DegU & $385 / 229$ & $32 / 28$ \\
Escherichia coli & NarX/NarP, NarL & $598 / 215,216$ & $31 / 33,32$ \\
\hline
\end{tabular}

a $\%$ Identities from a BLASTP search of HrpX and HrpY with default parameters, except for no filtering for low complexicity regions. Only the transmitter domain of HrpX (residues 273 to 494) was used for comparisons with other sensor proteins.

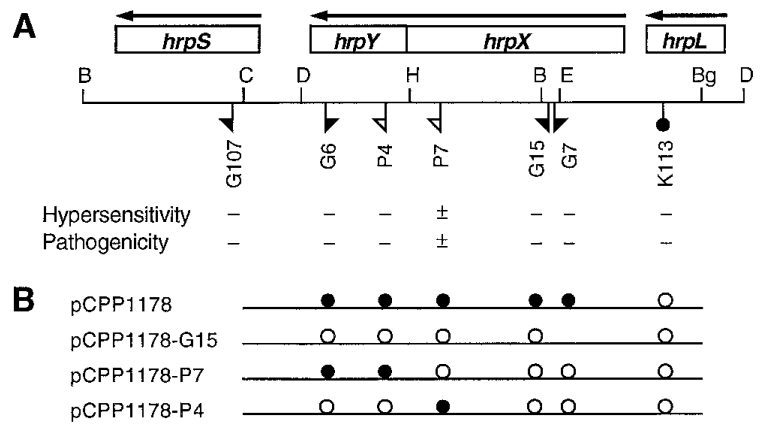

Fig. 3. Genetic characterization of the $h r p X Y$ locus. A, Locations of transposon insertions and phenotypes of $h r p X$ and $h r p Y$ mutants of $E r$ winia amylovora Ea321. Rectangles above map of restriction enzymes and transposons represent transcriptional units. Arrows: directions of transcription. Closed flags: insertions by Tn5-gusA1. Open flags: insertions by TnphoA. Llollipop: a Tn 10 -miniKm insertion. Mutants shown by minus signs below insertion points did not elicit the hypersensitve reaction $(\mathrm{HR})$ or cause disease $\left(\mathrm{Hrp}^{-}\right)$; a mutant shown by \pm infrequently elicited spotty HR and showed low virulence. B, Complementation assay of $h r p X$ and $h r p Y$ mutants of E. amylovora Ea321 with various plasmids. Closed circle: plasmid complemented Hrp phenotype of the mutant containing the transposon insertion in the same column. Open circle: plasmid did not change the phenotype of corresponding mutant. helix-turn-helix DNA binding motif. HrpY also has a sequence that matches the Myc-type helix-loop-helix dimerization domain signature (PROSITE:PS00038), the functional significance of which remains to be tested.

\section{Genetic characterization of $h r p X$ and $h r p Y$.}

The $h r p X Y$ locus in pCPP430 was mutagenized with transposons Tn5-gusAl and TnphoA. Derivatives of pCPP430 containing the transposon insertions were marker-exchanged into the genome of E. amylovora Ea321. All hrpY mutants of Ea321 failed to elicit the HR in tobacco and to infect immature pear fruits (Fig. 3A). Two classes of $h r p X$ insertion mutants were obtained. Ea321-G15 and Ea321-G7, which were made with Tn5-gusAl, were similar to $h r p Y$ mutants in phenotypes. Ea321-P7, an hrpX::TnphoA mutant, caused slight tissue collapse in tobacco at higher inoculum dose and had low virulence in immature pears, rather than the strict $\mathrm{Hrp}^{-}$ phenotype (Fig. 3A). Specifically, tobacco leaves infiltrated with Ea321-P7 at $\geq 5 \times 10^{8} \mathrm{CFU}$ per $\mathrm{ml}$ developed a spotty HR $36 \mathrm{~h}$ after infiltration. Also, in immature pears inoculated with the mutant, bacterial ooze appeared 3 days later than in those inoculated with the wild type, and the population of the mutant recovered was only one-tenth of that of the wild type (data not shown).

Virulence of the mutants was restored to near wild-type levels by providing the mutants with pCPP1178 in trans (Fig. 3B). The hrpX::Tn5-gusAl mutants of Ea321 were not complemented by pCPP1178-P4 that contains a transposon insertion in $h r p Y$ (Fig. 3B). This suggests that $h r p X$ and $h r p Y$ are in the same transcriptional unit and the Tn5-gusAl mutations in $h r p X$ are polar. We found, however, that the $h r p X:: \operatorname{Tn} p h o A$ mutant Ea321-P7 can be complemented by pCPP1178-P4, indicating that the TnphoA insertion of $h r p X$ did not affect the function of $h r p Y$ (Fig. 3B). TnphoA-induced mutations that permit the expression of downstream genes have been observed frequently in E. amylovora (Z. Wei and S. V. Beer, unpublished data) and Pseudomonas syringae (Huang et al. 1995a). Thus, we believe that the P7 insertion is nonpolar and that the peculiar phenotype of the Ea321-P7 may reflect the function of $h r p X$.

All the transposon mutations in the $h r p X Y$ locus were complemented by derivatives of pCPP430 with transposon insertions in hrpS or hrpL (data not shown), confirming the suggestion from sequence analysis that $h r p X$ and $h r p Y$ constitute an independent complementation group. Based on results of sequence analysis and genetic characterization, we conclude (i) $h r p X Y$ is required for the Hrp phenotype, and (ii) $h r p X$ and $h r p Y$ constitute a two-gene operon, $\operatorname{hrpXY}$.

\section{Expression of $\boldsymbol{h r p} X Y$ is environmentally regulated.}

A new construct, pCPP1203, was used to monitor expression of the $h r p X Y$ promoter in a nutrient-rich medium and a minimal medium that induces the expression of hrp genes (Wei et al. 1992). pCPP1203 was derived from pCPP1178G15 (hrpX::Tn5-gusAl) in which the directions of hrpX and gusA are the same. pCPP1178-G15 was digested with BamHI and $S a c I$ (an SacI site is present in the vector), which cuts out the $h r p X Y$ promoter region, a $5^{\prime}$ portion of the $h r p X$ coding region fused to Tn5-gusAl, and the whole transposon. The resulting fragment was then ligated to pCPP43, which had been digested with the same enzymes. pCPP43 (gift of David 
W. Bauer) is a derivative of pOU61, which is a low-copynumber plasmid (approximately one copy per bacterium at $30^{\circ} \mathrm{C}$ ) (Larsen et al. 1984).

In E. amylovora and Escherichia coli, the hrpXY promoter directed high levels of basal expression in Luria broth (LB), but expression of hrpX::Tn5-gusAl was enhanced threefold in the hrp-inducing minimal medium (IM) (Table 2). Enhanced levels of $h r p X:: T n 5$-gusAl expression were also observed from assays of the strains in tobacco leaves and immature pears (data not shown). No $\beta$-glucuronidase (GUS) activity was detected for

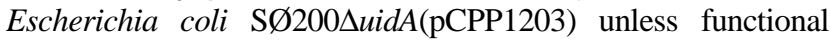
$h r p X Y$ was provided (Table 2). Similarly, high basal-level expression of $h r p X:: T n 5-g u s A 1$ of Ea321(pCPP1203) in Table 2 is probably due to functional $h r p X Y$ present in the chromosome. The latter two observations indicate that $h r p X Y$ is also autoregulated.

\section{$h r p X$ and $h r p Y$ control the expression of $h r p L$.}

To study the effect of $h r p X$ and $h r p Y$ on the control of $h r p L$ expression, a hrpL::Tn5-gusAl fusion (pCPP139-G44) (Wei and Beer 1995) was marker exchanged into an $h r p X$ mutant (Ea321-P7) and an $h r p Y$ mutant (Ea321-P4), to generate $h r p X-$ $h r p L$ and $h r p Y-h r p L$ double mutants Ea321-P7G44 and Ea321-P4G44, respectively. Mutation in hrpY completely abolished $h r p L$ expression (Fig. 4). However, the $h r p X$ mutant reduced $h r p L$ expression only to about $20 \%$ of its wild-type level, opening the possibility that the mutated HrpX may be still partially functional or another sensor protein may cross talk with HrpY.

\section{Analysis of the hrpS locus and the ORFs between hrpS and hrpA.}

$h r p S$ also partially controls $h r p L$ expression in E. amylovora and is located downstream of $h r p X Y$ (Wei and Beer 1995). We report here the entire nucleotide sequence of the region between $h r p Y$ and $h r p A$, which includes $h r p S$, to complete the preliminary results on $h r p S$ presented previously (Sneath et al. 1990).

The hrpS locus of E. amylovora Ea321 contains a single-gene operon, based on the large intergenic regions beyond the coding region of $h r p S$, and a potential terminator, CGGCGACAGC-N ${ }_{8^{-}}$ GCTGTCGCCG, that lies 49 bp downstream of the $h r p S$ stop codon. The hrpS ORF is preceded by a potential $\sigma^{70}$ promoter, GTGGCA-N ${ }_{18}$-TATTAC (score from promoter prediction by neural network $=0.96$ ), and it encodes a 324 amino acid protein. HrpS has homology to members of the $\sigma^{54}$-dependent, enhancerbinding protein family (Morett and Segovia 1993). HrpS shows highest sequence similarity with WtsA (HrpS) of Erwinia (Pantoea) stewartii (Frederick et al. 1993) (79\% identity over 322 amino acid residues without gaps from BLASTP), HrpR and HrpS of $P$. syringae pathovars (51 to 55\% identities) (Grimm et al. 1995; Xiao et al. 1994), and DetD of Rhizobium spp. (39\% identities) (Jiang et al. 1989; Ronson et al. 1987). HrpS of E. amylovora has two putative ATP-binding sites at the $\mathrm{N}$ terminus and a helix-turn-helix DNA-binding motif at the $\mathrm{C}$ terminus (Fig. 5A). HrpS shows high sequence similarity to other regulators in the $\mathrm{NtrC}$ family throughout the entire $\sigma^{54}$ interaction domain. However, similar to other HrpR/HrpS proteins, HrpS of E. amylovora contains a very short N-terminal A domain (Shingler 1996), and seems to lack the phosphorylation receiver domain (Fig. 5A).
In the region between $h r p S$ and $h r p A$, three potential genes, designated orfU0, orfU1, and orfU2 (Fig. 1B), were identified by application of the GeneMark.hmm algorithm (Lukashin and Borodovsky 1998). orfUO is a small ORF encoding a 46 amino acid basic protein, without significant similarity to any protein in the data base. Preceded by GGAGT 8 bp upstream, orfU1 encodes a 203 amino acid basic protein that is similar to a conserved hypothetical protein HP1401 of Helicobacter pylori (32\% identity over 164 amino acid residues with 12 gaps) (Fig. $5 \mathrm{~B})$. Interestingly, protein sequence of the next ORF, orfU2, shows even higher similarity to HP1401 (residues 189 to 229; $41 \%$ identity without gaps). This suggests the possibility that a frame shift in orfU1-orfU2 resulted in the two current ORFs, and that both may be defective. The lack of an obvious promoter in front of orfUO, the lack of good ribosome-binding sites in front of orfUO and orfU2, the potential frame-shift mutation at the $3^{\prime}$ region of orfUl, and the lack of a phenotype of TnphoAinduced orfU1 mutants (data not shown) indicate that the region comprising orfU0-orfU2 is unlikely to be functional in Ea321.

Expression of $\mathrm{hrpS}$ is not autoregulated, and induction of $h r p S$ is independent of $h r p X$ or $h r p Y$.

An hrpS::gusAl fusion designated G107 (Wei et al. 1992) was used to assay the expression of hrpS. A fragment of

Table 2. Expression of the $h r p X Y$ promoter in Luria broth (LB) and in a $h r p$-inducing minimal medium (IM)

\begin{tabular}{lcc}
\hline & \multicolumn{2}{c}{ GUS activity } \\
\cline { 2 - 3 } Bacterial strain $^{\mathbf{b}}$ & LB & IM \\
\hline Erwinia amylovora Ea321(pCPP1203) & $242 \pm 12$ & $788 \pm 32$ \\
E. coli S $\varnothing 200 \Delta$ uidA(pCPP1203) & $2 \pm 3$ & $3 \pm 3$ \\
E. coli S $\varnothing 200 \Delta$ uidA(pCPP1203, pCPP1178) & $145 \pm 19$ & $878 \pm 33$ \\
\hline a $E$. coli S $\varnothing 200 \Delta u i d A$ is an Escherichia coli strain with no $\beta$-glucuron- \\
idase (GUS) activity due to deletion of gusA. pCPP1203 is a low-copy- \\
number plasmid containing hrpX::Tn5-gusA1; pCPP1178 is a high- \\
copy-number plasmid containing functional hrpX and hrpY genes. \\
b Picounits per CFU; mean of three replicates \pm standard deviation.
\end{tabular}

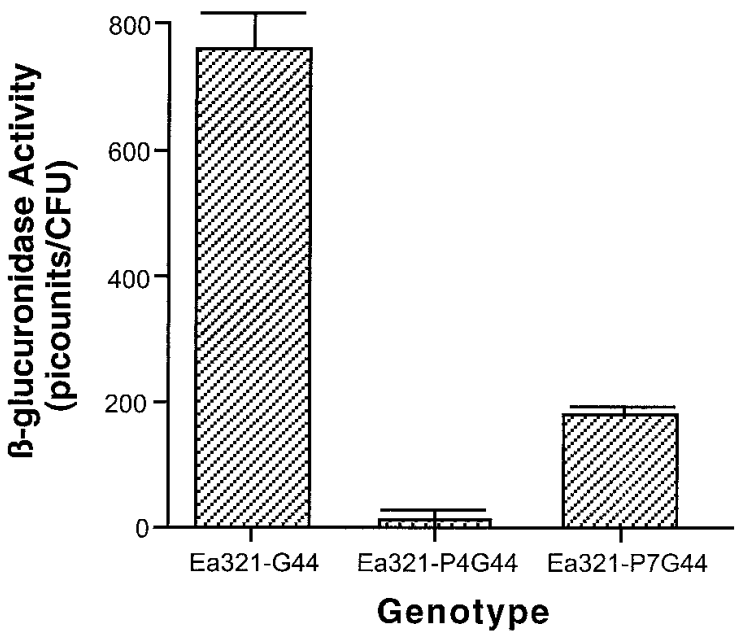

Fig. 4. Effect of mutations in $h r p X$ and $h r p Y$ on expression of $h r p L$. Genotypes of the strains are Ea321-G44, hrpL::Tn5-gusA1 (Wei and Beer 1995); Ea321-P4G44, hrpY::TnphoA and hrpL::Tn5-gusA1; and Ea321-P7G44, hrpX::TnphoA and hrpL::Tn5-gusA1. Error bars: standard deviation from three replicates. Cells grown in inducing medium (IM) were assayed (see Materials and Methods for details). 
pCPP430-G107 digested with BamHI contains the whole transposon, the hrpS gene fused to Tn5-gusAl, and the hrpS promoter region. This BamHI fragment was ligated with a lowcopy-number plasmid, pCPP8 (Bauer 1990), that was cut with the same enzyme. The resulting plasmid was designated pCPP1058. As with $h r p X Y$, expression of hrpS in Escherichia coli or in E. amylovora was induced under hrp-inducing conditions (Table 3). However, autoregulation was not required for $h r p S$ expression; the presence of functional $h r p S$ did not affect the expression of a $\operatorname{hrpS}:$ :gusAl fusion in pCPP1058 (Table 3).
To determine whether the newly discovered two-component system has any effect on the expression of $h r p S$, an hrpS::Tn5-gusAl fusion (pCPP430-G107) was marker-exchanged into $h r p X$ and $h r p Y$ mutants. Neither $h r p X$ nor $h r p Y$ affected $h r p S$ expression significantly (Fig. 6).

\section{$h r p S$ and $h r p L$, provided by multicopy plasmids, suppress defects in $h r p X$ or $h r p Y$.}

To further characterize the regulatory relationships between $h r p X Y, h r p S$, and $h r p L$, the HR-impaired strains Ea321-P7, Ea321-P4, and Ea321-G107 were transformed with pCPP1178

A

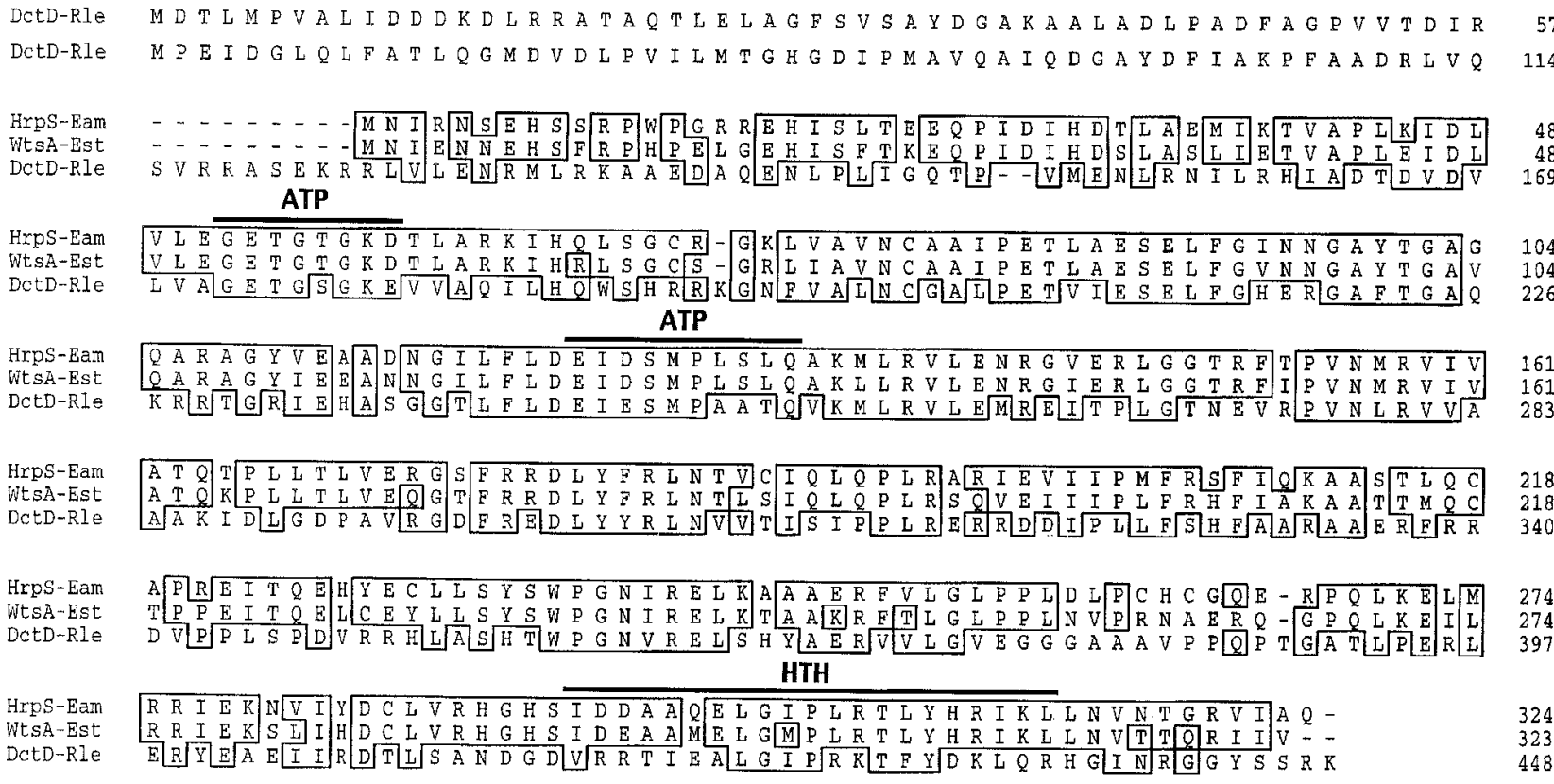

B

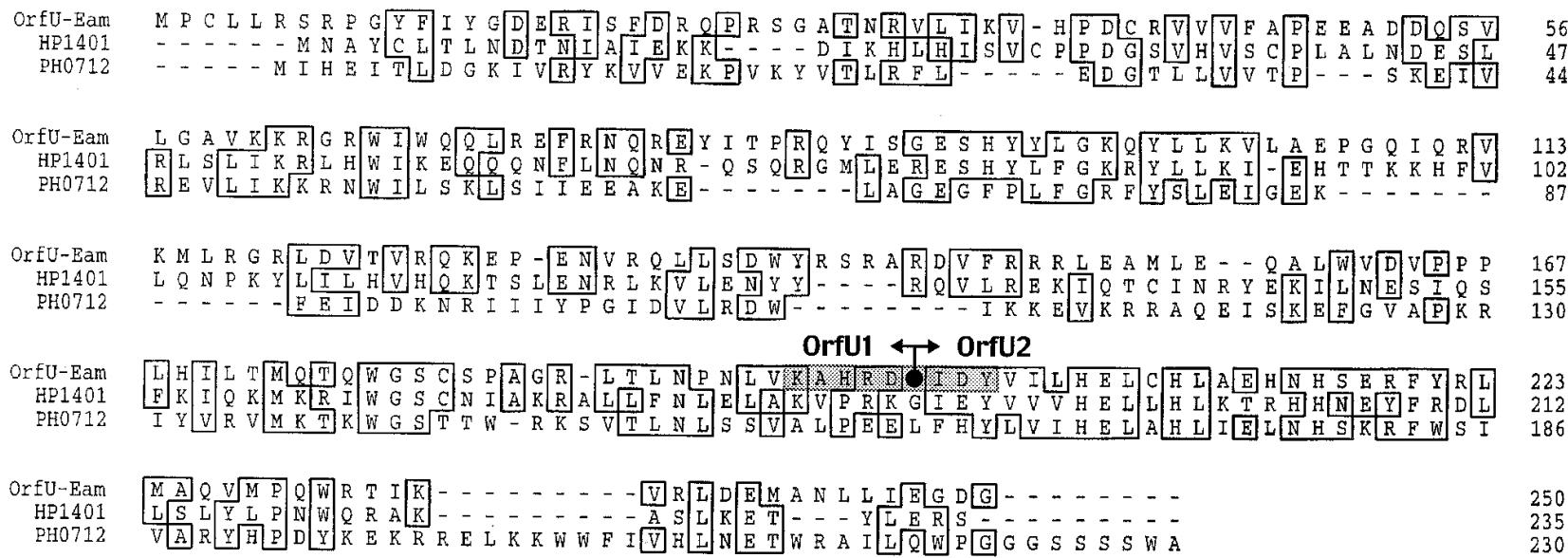

Fig. 5. Alignments of A, HrpS, and $\mathbf{B}$, OrfU of Erwinia amylovora with similar proteins. PILEUP program (GCG software package, version 7.3; Genetics Computer Group, Madison, WI, U.S.A.) with default parameters was used to align the sequences. Overlines represent ATP-binding sites (ATP) and the helix-turn-helix DNA-binding motif $(\mathrm{HTH})$. Sequence of OrfU is a composite of sequences of orfU1 and orfU2 products. A putative tyrosine kinase phosphorylation site (PROSITE: PS00007) is indicated by shading. Black circle in the OrfU sequence denotes location of a probable reading-frame shift. Accession numbers: WtsA of E. stewartii, SWISS-PROT:P36219; DctD of Rhizobium leguminosarium, SWISS-PROT:P10046; HP1401 of Helicobacter pylori, GENBANK:AE000640; and PH0712 of Pyrococcus horikoshii, DDBJ:AP000003. 
(contains $h r p X Y$ ), pCPP1001 (contains hrpS) (Wei and Beer 1995), or pCPP1078 (contains hrpL) (Wei and Beer 1995). The resulting transformants were infiltrated into panels of tobacco leaves to determine which, if any, of the regulatory genes, when present in multiple copies, are sufficient to restore the HR-eliciting ability to the mutants. Panels infiltrated with $h r p X$ and $h r p Y$ mutants containing hrpL developed the HR (Table 4), often faster than panels infiltrated with the wildtype strain. The panels began to show collapse 8 to $12 \mathrm{~h}$ after infiltration; by $24 \mathrm{~h}$, the whole infiltrated area had collapsed in a typical HR. This result is consistent with dependence of $h r p L$ expression on $h r p X$ and $h r p Y$. Interestingly, similar suppression was observed from $h r p X$ and $h r p Y$ mutants containing $h r p S$, whereas $h r p X$ and $h r p Y$ did not restore the HR phenotype of the hrpS mutant (Table 4).

\section{DISCUSSION}

The HrpX/HrpY two-component protein system.

Our results demonstrate that E. amylovora employs the HrpX/HrpY two-component regulatory proteins to direct expression of an alternate sigma factor gene, $h r p L$, that in turn activates a type III protein secretion system. This provides for a quick change in the pattern of gene expression needed to initiate infection. HrpX is a putative $\mathrm{I}_{\mathrm{C}} \mathrm{T}$-type sensor (Parkinson and Kofoid 1992) composed of the N-terminal PAS domain and the C-terminal histidine kinase domain (Fig. 2A). HrpX appears to be cytoplasmic, and may be anchored to the inner membrane by its internal hydrophobic region. Other members of the PAS-containing $\mathrm{I}_{\mathrm{C}} \mathrm{T}$-type sensor kinases include NifL, NtrB, and KinA (Zhulin et al. 1997). HrpY appears to be a $\mathrm{RO}_{\text {III }}$ subfamily response regulator (Parkinson and Kofoid 1992). Consistent with the HrpX transmitter domain, HrpY shows significant sequence similarity to VsrD, DegU, UhpA, and NarL.

Two-component systems with PAS domains in the sensor component include NifL/NifA, DctS/DctR, and BvgS/BvgA (Zhulin et al. 1997). Among these only NifL does not contain the periplasmic domain, and HrpX is more similar to NifL than the other two. NifL and most other PAS-containing proteins are sensors (Zhulin et al. 1997), and their signal input domains are located at the $\mathrm{N}$ terminus (Parkinson and Kofoid 1992). Thus, HrpX may directly perceive environmental signals with its N-terminal PAS domain. One function of the PAS domain is to act as a protein dimerization motif (Kay 1997). This raises the possibility of $\mathrm{HrpX}$ dimerization, which is required for the functional state of two-component sensors (Parkinson and Kofoid 1992).

\section{Two-component regulatory system and type III protein secretion.}

Although the two-component system is widely used to control bacterial gene expression (Hoch and Silhavy 1995), reports of its function in regulation of the type III system are just emerging. In $S$. typhimurium, SirA is a response regulator essential for induction of hilA, prgHIJK, and sigDE (Hong and Miller 1998; Johnston et al. 1996), and the PhoQ/PhoP twocomponent system represses the expression of the prg locus (Pegues et al. 1995). The CpxA/CpxR system controls the $\mathrm{pH}-$ dependent expression of the Shigella sonnei virF gene, which in turn activates ipaBCD and virG (Nakayama and Watanabe
Table 3. Expression of the hrpS promoter in Luria broth (LB) and in hrp-inducing minimal medium (IM)

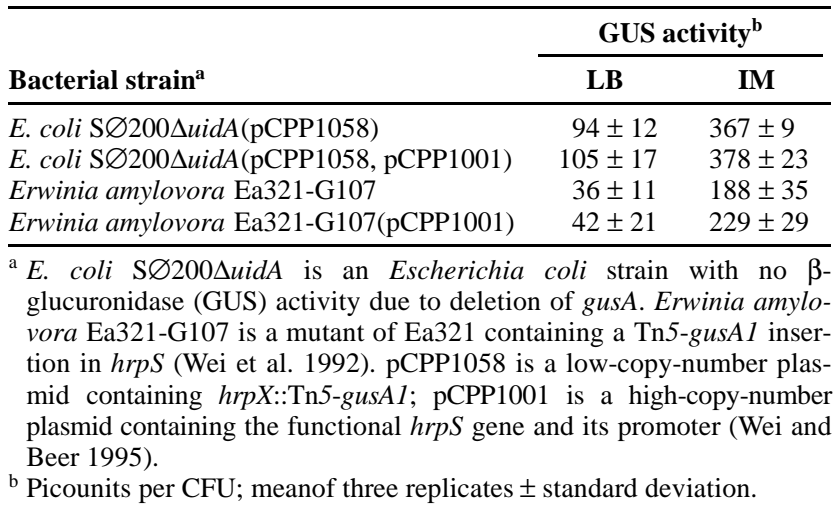

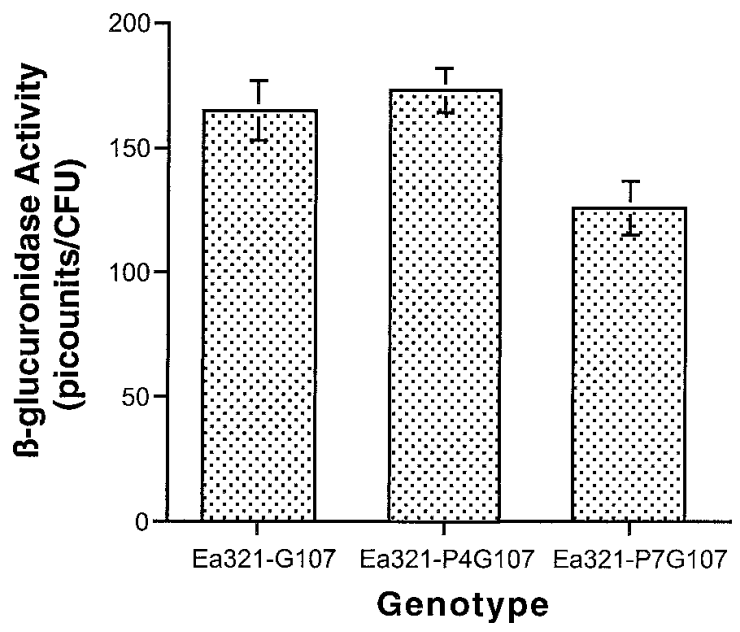

Fig. 6. Effect of mutations in $h r p X$ and $h r p Y$ on expression of $h r p S$. Genotypes of the strains are Ea321-G107, hrpS::Tn5-gusAl (Wei et al. 1992); Ea321-P4G107, hrpY::TnphoA and hrpS::Tn5-gusA1; and Ea321P7G107, hrpX::TnphoA and hrpS::Tn5-gusA1. Error bars: standard deviation for three replicates. Cells grown in inducing medium (IM) were assayed (Materials and Methods contains details).

Table 4. Hypersensitive reaction (HR) elicitation by $h r p$ regulation mutants

\begin{tabular}{llc}
\hline Strain & \multicolumn{1}{c}{ Genotype } & HR phenotype ${ }^{\mathbf{a}}$ \\
\hline Ea321 & wild type; $h r p^{+}$ & +++ \\
Ea321-P7 & $h r p X$ & \pm \\
Ea321-P7(pCPP1178) & $h r p X\left(h r p X Y^{+}\right)$ & $++^{\mathrm{b}}$ \\
Ea321-P7(pCPP1001) & $h r p X\left(h r p S^{+}\right)$ & +++ \\
Ea321-P7(pCPP1078) & $h r p X\left(h r p L^{+}\right)$ & +++ \\
Ea321-P4 & $h r p Y$ & - \\
Ea321-P4(pCPP1178) & $h r p Y\left(h r p X Y^{+}\right)$ & ++ \\
Ea321-P4(pCPP1001) & $h r p Y\left(h r p S^{+}\right)$ & +++ \\
Ea321-P4(pCPP1078) & $h r p Y\left(h r p L^{+}\right)$ & +++ \\
Ea321-G107 & $h r p S$ & - \\
Ea321-G107(pCPP1178) & $h r p S\left(h r p X Y^{+}\right)$ & - \\
Ea321-G107(pCPP1001) & $h r p S\left(h r p S^{+}\right)$ & +++ \\
\hline
\end{tabular}

a +++ , full HR manifested by complete tissue collapse throughout infiltrated area; ++, reduced HR, which is spotty and often coalescing; \pm , infrequent collapse and small spotty necreosis for HR-positive leaves; and - , no HR. Inoculum concentration was approximately $2 \times 10^{8} \mathrm{CFU}$ per ml. Ratings (consensus of four plants) were made $36 \mathrm{~h}$ after inoculation.

${ }^{b}$ Full HR was observed at inoculum levels of $\geq 5 \times 10^{8} \mathrm{CFU}$ per ml. 
1995). Also, the BvgS/BvgA system was recently found to be involved in the regulation of the type III secretion in Bordetella bronchiseptica (Yuk et al. 1998). Among plant pathogens, HrpG of Xanthomonas campestris pv. vesicatoria, a homolog of response regulators, has been shown to regulate $h r p X v$ and hrpA expression (Wengelnik et al. 1996).

The structure of the input domain of E. amylovora HrpX appears to be exceptional, compared with sensor proteins involved in other type III systems, which contain two transmembrane regions and a periplasmic domain. The closest homologs of E. amylovora HrpY are SirA and BvgA, both of which are $\mathrm{RO}_{\mathrm{III}}$-type regulators (Parkinson and Kofoid 1992), whereas $X$. campestris $\mathrm{HrpG}$ belongs to the $\mathrm{RO}_{\mathrm{II}}$ type, which includes Escherichia coli CpxR and OmpR, S. typhimurium PhoP, and Agrobacterium tumefaciens VirG. Thus, at least two types of transmitter-receiver systems appear to have evolved for control of type III systems in response to environmental stimuli in hosts. Also, the two two-component systems identified in the plant pathogens E. amylovora and $X$. campestris fall into different communication groups.

HrpS and mechanism of gene regulation.

HrpS is a member of the $\sigma^{54}$-dependent, enhancer-binding protein family. Both hrpS and rpoN are required for transcrip- tion of hrp genes in P. syringae pathovars (Grimm et al. 1995; Xiao et al. 1994). WtsA (HrpS) of E. stewartii controls expression of $w t s B$, which also requires the presence of $\sigma^{54}$ (Frederick et al. 1993). In E. amylovora, HrpS partially regulates $h r p L$ expression (Wei and Beer 1995), and a sequence, TGGCAC-N ${ }_{5}$-TTGC, that perfectly matches the $-24 /-12$ promoter consensus sequence is found at the promoter region of E. amylovora hrpL. The hrpS gene of E. amylovora, but not hrpS of $P$. syringae pv. phaseolicola, can complement the hrpS mutation in E. stewartii (Frederick et al. 1993). The HrpS sequences of the two erwinias are highly similar, and even the upstream noncoding regions appear to be conserved, except for the insertion of a 484-bp sequence, reminiscent of an IS (insertion sequence) element, 23-bp upstream of the $E$. stewartii hrpS ORF.

As a member of the NtrC family, HrpS is unusual in that it lacks a long $\mathrm{N}$-terminal receiver domain. Control of protein activation by phosphorylation, by protein-protein interaction, and by signal molecule have been suggested for $\sigma^{54}$-dependent proteins (Shingler 1996). In the direct activation model, derepression by effectors seems to be a mechanism of protein activation. For DctD, DmpR, and XylR, deletion of the receiver domain results in constitutive activation of the proteins, suggesting that the receiver domain has a repressor function

\section{Plant apoplast}

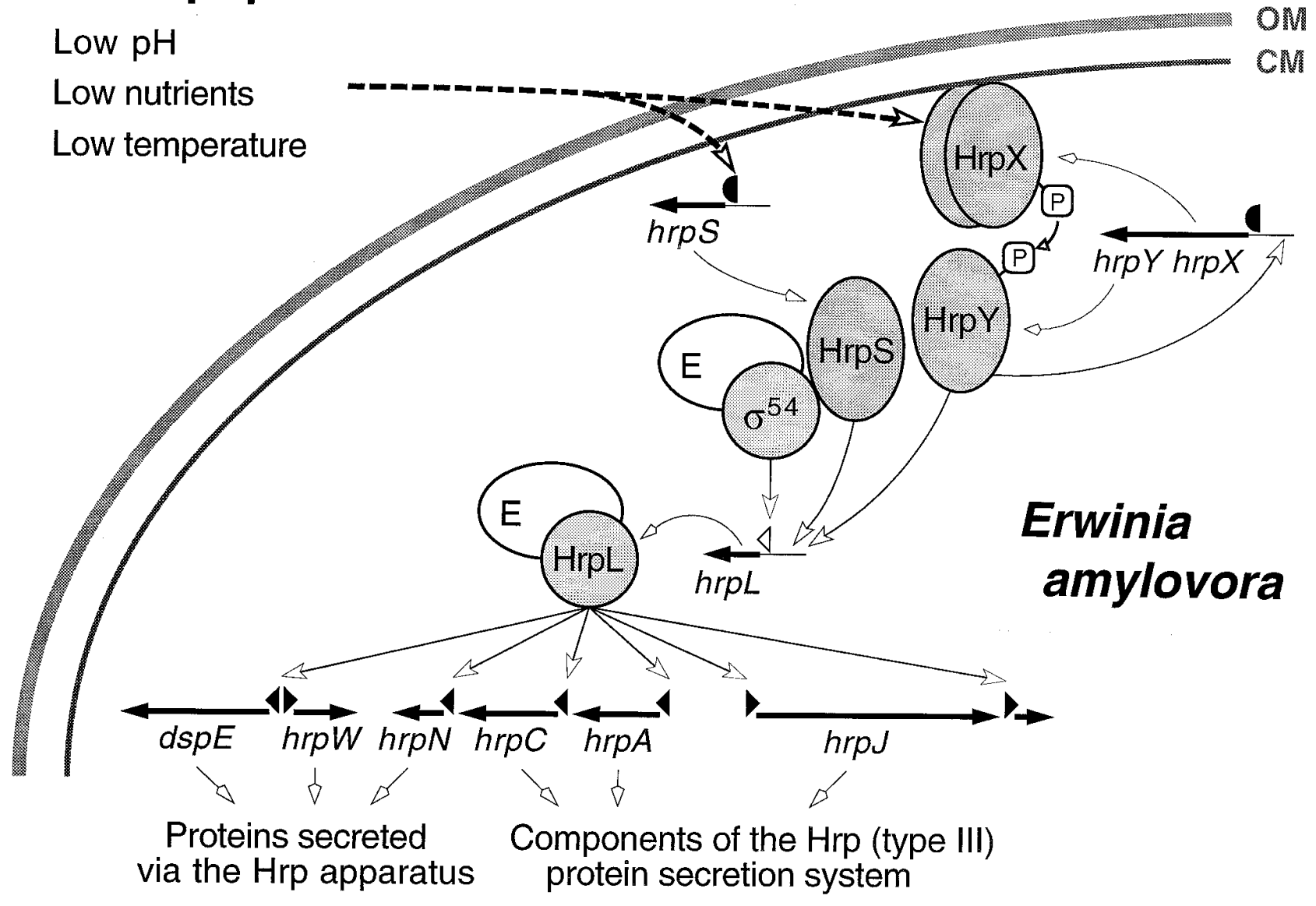

Fig. 7. Model of the hrp gene regulatory cascade. Thick arrow lines: genes or operons. Ovals and circles: proteins. Arrowheads in thinner lines: directions of information flow. CM, cytoplasmic membrane; OM, outer membrane; P, phosphate; E, RNA polymerase; closed half circle, $\sigma^{70}$ promoter; open triangle, $\sigma^{54}$ promoter; and filled triangle, HrpL promoter. 
(Shingler 1996). Therefore, the apparent absence of the receiver domain in HrpS implies that HrpS may not require phosphorylation for activation and is always active once the protein is made.

\section{Induction of $h r p X Y$ and $h r p S$ and the involvement of HrpXY and HrpS in $h r p L$ regulation.}

Expression of hrpS and $h r p X Y$ is induced by conditions that mimic the apoplastic environment (Wei et al. 1992; this work). $\operatorname{hrpXY}$ shows high basal-level expression, and autoregulation is involved in gene induction. However, hrpS is not autoregulated based on results of the GUS assay, suggesting that there may be upstream regulatory components. Although $h r p S$ provided in multiple-copy plasmids reverses the $\mathrm{Hrp}^{-}$phenotype of $h r p X$ and $h r p Y$ mutants, the independence of $h r p S$ from $h r p X$ and $h r p Y$ suggests that $h r p X Y$ is not epistatic to $h r p S$ and environmental signals may go to hrpS through a different pathway.

Earlier work on $h r p L$ and $h r p S$ (Wei and Beer 1995) established that HrpS partially controls $h r p L$ expression. Our current work indicates that the HrpX/HrpY system contributes to $h r p L$ induction. Based on the role of $h r p X Y$ and $h r p S$ in regulating $h r p L$ and the lack of effect of $h r p X$ and $h r p Y$ in $h r p S$ expression, one might place $h r p S$ upstream of $h r p X Y$. This notion is precluded, however, because $h r p X Y$ does not override $h r p S$ mutation. As mentioned above, the opposite is not likely, either. Therefore, it seems that signals independently perceived by $h r p X Y$ and $h r p S$ converge at $h r p L$.

Neither HrpS nor HrpY alone induce high levels of $h r p L$ expression, suggesting that cooperation of HrpY and HrpS, possibly through protein-protein interaction, may be needed for full activation of $h r p L$. In this model, HrpS may be a positive activator of $h r p L$, while HrpX/HrpY may act as a modulator of $h r p L$ transcription. Complementation of $h r p X$ and $h r p Y$ mutants for the HR phenotype by overexpressed $h r p S$ supports this model. The regulation of eps genes of $R$. solanacearum seems similar; both VsrD and PhcA regulators bind to the $x p s R$ promoter region and control xpsR expression (Huang et al. 1995b). In $P$. syringae pv. syringae, HrpR and $\mathrm{HrpS}$ have been proposed to work together to control hrpL expression (Xiao et al. 1994), although a different opinion exists for homologous proteins in $P$. syringae pv. phaseolicola (Grimm et al. 1995).

\section{hrp gene regulation and Hrp phenotypes.}

$h r p Y$ and $h r p S$ seem to be crucial to the pathogenic life-style of E. amylovora, since their inactivation by mutagenesis results in loss of pathogenicity in immature pears (Wei et al. 1992; this work). The hrpX mutant, however, shows an attenuated phenotype: slightly lowered hrpL expression and reduced HR and virulence at higher inoculum doses. Currently, we cannot rule out the possibility of partial HrpX function in that mutant, even though leaky phenotypes of sensor mutants have been documented for other two-component systems (Stock et al. 1989). It is interesting to note that, although $h r p X$ and $h r p S$ mutants show different phenotypes (the former reduced $\mathrm{Hrp}$ and the latter $\mathrm{Hrp}^{-}$), both are similarly affected in $h r p L$ expression, i.e., only three- to fourfold reduction. This suggests that either there is a threshold level of hrp gene expression required for causing disease, or $h r p S$ is involved in expression of other genes that contribute to pathogenicity. Further study might distinguish between these two possibilities.
The incomplete complementation of $h r p X$ and $h r p Y$ mutants by $h r p X Y$ provided in a multicopy plasmid at lower inoculum levels $\left(\leq 2 \times 10^{8} \mathrm{CFU}\right.$ per $\left.\mathrm{ml}\right)$ is intriguing and deserves further investigation. One explanation for the results could be that defective HrpX and HrpY in the mutants interact with functional HrpX and HrpY, and, possibly by forming heterodimers, interfere with the full activity. Alternatively, overproduced HrpX and HrpY may somehow down-regulate $h r p S$ expression.

\section{Model of the E. amylovora hrp gene expression.}

Based on previous studies (Bogdanove et al. 1996, 1998b; Kim and Beer 1998; Kim et al. 1997; Wei and Beer 1995; Wei et al. 1992) and results described in this work, we propose a scheme of hrp gene regulation in E. amylovora (Fig. 7). When the bacteria enter the plant apoplast, HrpX perceives environmental signals and is phosphorylated. Activated HrpX then phosphorylates HrpY to activate it, and increases the expression of $h r p X Y$ to produce more HrpX and HrpY. Independently, expression of $h r p S$ is induced in response to the changed environment. Activated HrpY and HrpS, bound to the hrpL promoter, then interact with the RNA polymerase- $\sigma^{54}$ complex to drive transcription of $h r p L$. HrpS also activates other genes containing the $-24 /-12$ promoter consensus sequence. Finally, the $\operatorname{HrpL} \sigma$ factor, which recognizes a conserved promoter motif, GGAACC- $\mathrm{N}_{15}$-CCACTAAT, directs transcription of the remaining $h r p$ and $d s p$ genes that produce the secretion machinery and virulence proteins that interact with plant cells.

\section{MATERIALS AND METHODS}

\section{Bacterial strains and growth condition.}

E. amylovora Ea321 is a wild-type strain that infects pear and apple (Beer et al. 1991). Escherichia coli DH5 $\alpha$ was routinely used for cloning of cosmids and plasmids. pCPP1001 (Wei and Beer 1995), pCPP1036 (Kim et al. 1997), pCPP1078 (Wei and Beer 1995), and pCPP1178 are subclones of pCPP430 (Beer et al. 1991), and contain ORFs in the same direction as the T7 $\Phi 10$ promoter from the vector pBluescript $\mathrm{KS}+$. Strains of E. amylovora Ea321 and Escherichia coli were grown in LB (Sambrook et al. 1989) with vigorous shaking at 28 and $37^{\circ} \mathrm{C}$, respectively. Inducing medium (IM) was used for inducing hrp gene expression as described previously (Wei et al. 1992). The antibiotics used to maintain selection were ampicillin at $100 \mu \mathrm{g} / \mathrm{ml}$, kanamycin $(\mathrm{Km})$ at $50 \mu \mathrm{g} / \mathrm{ml}$, spectinomycin (Sp) at $50 \mu \mathrm{g} / \mathrm{ml}$, tetracycline (Tc) at $20 \mu \mathrm{g} / \mathrm{ml}$, and carbenicillin $(\mathrm{Cb})$ at $300 \mu \mathrm{g} / \mathrm{ml}$.

\section{Recombinant DNA techniques and sequence analysis.}

Unless otherwise specified, basic molecular biology techniques were as described (Sambrook et al. 1989). Electroporation of plasmid DNA into E. amylovora 321 and its derivatives was done as described by Bauer and Beer (1991) with the Gene Pulser apparatus (Bio-Rad, Richmond, CA, U.S.A.).

Deletion clones, generated from the ClaI-BglII insert in pCPP1178 with the Erase-A-Base kit (Promega, Madison, WI, U.S.A.), were sequenced by the dideoxy chain termination procedure with the Sequenase sequencing kit (U.S. Biochemical, Cleveland, OH, U.S.A.). Also, sequencing of the region between $h r p A$ and $h r p J$ in pCPP430, pCPP1001, pCPP1036, and pCPP1178 was performed on an ABI 373A automated DNA sequencer (Perkin-Elmer, Norwalk, CT, U.S.A.) at the 
Cornell University Biotechnology Program DNA Sequencing Facility with oligonucleotide primers synthesized at the same facility.

DNA and deduced amino acid sequences were analyzed with programs in the GCG software package, version 7.3 (Genetics Computer Group, Madison, WI, U.S.A.) and DNASTAR (DNASTAR, Madison, WI, U.S.A.). Potential genes were identified with GeneMark.hmm (Lukashin and Borodovsky 1998; available on-line from the GeneMark web site). Homology searches were done with BLAST algorithms (Altschul et al. 1997; available on-line from the NCBI web site). Conserved patterns in proteins were found with ScanProsite (Appel et al. 1994; available on-line). Finally, prediction of potential $\sigma^{70}$ promoters were made with the Promoter Prediction by Neural Network method (Reese and Eeckman 1995; available on-line).

\section{Expression of $\boldsymbol{h r p X}$ and $\boldsymbol{h r p Y}$ in Escherichia coli.}

A gene expression system mediated by a T7 RNA polymerase/promoter (Tabor and Richardson 1985) was used. pCPP1178, which contains $h r p X$ and $h r p Y$ ORFs driven by the T7 $\$ 10$ promoter from the vector, was introduced into Escherichia coli DH5 $\alpha$ (pGP1-2). Cells were incubated at $42^{\circ} \mathrm{C}$ to induce the expression of the T7 RNA polymerase gene, and newly synthesized proteins were radiolabeled with ${ }^{35} \mathrm{~S}-\mathrm{Met}$ as described (Tabor and Richardson 1985). Resulting samples were resuspended in a sample buffer and heated to $95^{\circ} \mathrm{C}$ for $3 \mathrm{~min}$ before being electrophoresed in a $12 \%$ polyacrylamide gel.

\section{Construction of marker-exchange mutants.}

Chromosomal mutants were constructed by markerexchange mutagenesis as described previously (Wei et al. 1992). A Tn10-miniKm insertion or a TnphoA insertion, mapped at the hrpXY or hrpL locus in Escherichia coli DH5(pCCPP430) or Escherichia coli DH5 $\alpha$ (pCPP1178), was introduced into E. amylovora Ea321 by triparental mating with the helper strain, Escherichia coli HB101(pRK600) (kindly provided by E. R. Signer; Department of Biology, Massachusetts Institute of Technology, Cambridge). The transconjugants were selected on Luria plates containing $\mathrm{Km}$ and $\mathrm{Sp}$, and then transferred to a low-phosphate minimal medium (Bauer 1990) to select for $\mathrm{Km}^{\mathrm{r}} \mathrm{Sp}^{\mathrm{s}}$ marker-exchanged mutants. The second mutations were generated by introducing individual hrp::Tn5-gusAl fusions into Tn10-miniKm or TnphoA mutants of Ea321. Since the transposon Tn5-gusA1 has two selection marker, $\mathrm{Km}$ and $\mathrm{Tc}$, the second mutation was selected based on $\mathrm{Km}^{\mathrm{r}} \mathrm{Tc}^{\mathrm{r}} \mathrm{Sp}^{\mathrm{s}}$ phenotype. All the mutants were tested for the HR-eliciting ability and pathogenicity. TnphoA insertions P74 and P86 in pCPP1036, which were mapped to orfU1, were introduced to the Ea321 genome by electroporation and subsequent incubation in a low-phosphate medium with $\mathrm{Km}$. Integration of the TnphoA fusion into the chromosome was confirmed by antibiotic resistance $\left(\mathrm{Km}^{\mathrm{r}} \mathrm{Cb}^{\mathrm{s}}\right)$ and Southern hybridization with the transposon DNA as a probe.

\section{Assay of GUS activity.}

Overnight cultures in LB were transferred to fresh LB, and incubated further. For incubation in IM, log-phase cultures in LB were centrifuged, and cells were washed with IM, before they are resuspended in $\mathrm{IM}$ to $\mathrm{OD}_{620} \approx 0.5$. The cultures in IM were incubated for an additional 5 to $6 \mathrm{~h}$ at $24^{\circ} \mathrm{C}$ before assay of GUS activity. GUS activity was monitored fluorimetrically as described by Jefferson et al. (1987). Forty-five microliters of the log-phase culture in LB or the induced culture from IM was mixed with an equal volume of $2 \times$ assay buffer. After incubation at $37^{\circ} \mathrm{C}$ for $10 \mathrm{~h}$, GUS activity was measured as described previously (Wei et al. 1992). The background fluorescence of Ea321-G77 ( $h r c V:: T n 5-g u s A 1)$ (Wei et al. 1992), which has a gusAl insertion in the opposite direction of $h r c V$ transcription, was subtracted from the readings of hrp::gusAl fusion strains. The corrected fluorescence readings were converted to picounits of GUS activity per CFU. The GUS activity of hrp::Tn5-gusAl fusions also were determined in tobacco leaf tissues as described previously (Wei et al. 1992).

\section{Plant assays.}

Bacteria were grown in LB and harvested at mid-exponential phase. Cells were resuspended in $5 \mathrm{mM}$ potassium phosphate buffer, $\mathrm{pH}$ 6.5, harvested again, resuspended in the potassium phosphate buffer to approximately $2 \times 10^{8} \mathrm{CFU}$ per $\mathrm{ml}$, unless otherwise specified, and used for HR and pathogenicity assays. Tobacco plants (Nicotiana tabacum L. 'Xanthi') were grown in greenhouse soil mix to a height of 0.9 to $1 \mathrm{~m}$. Bacterial suspensions were infiltrated into each leaf panel of tobacco leaves with needleless hypodermic syringes. The development of the HR was scored after incubation at room temperature for 18 to $36 \mathrm{~h}$. Pathogenicity tests on immature pear fruits were carried out as previously described (Bauer and Beer 1991; Steinberger and Beer 1988).

\section{ACKNOWLEDGMENTS}

We acknowledge Barbara J. Sneath for her initial characterization of the hrpS locus, David W. Bauer for providing pCPP43, and Pakorn Kanchanawong for assisting with the epistasis experiment. We thank Adam J. Bogdanove, Stephen C. Winans, and anonymous reviewers for critical reading and suggestions. This work was supported by USDA CGRO grant 91-3-7303-6430, by USDA Special Research grant 9934367-7990, by Eden Bioscience Corporation, Bothell, WA, and by the Cornell Center for Advanced Technology (CAT) in Biotechnology, which is sponsored by the New York State Science and Technology Foundation and industrial partners.

\section{NOTE ADDED IN PROOF}

A recent BLAST survey of finished and unfinished microbial genomes (available on-line from the NCBI web site) suggests the presence in Pseudomonas aeruginosa PAO1 of a two-component system that is highly similar to the HrpX/HrpY system (31\% identity over 474 amino acids for HrpX and $48 \%$ identity over 208 amino acids for HrpY). A related set of proteins exist in the Pseudomonas putida KT2440 genome.

\section{LITERATURE CITED}

Alfano, J. R., and Collmer, A. 1996. Bacterial pathogens in plants: Life up against the wall. Plant Cell 8:1683-1698.

Altschul, S. F., Madden, T. L., Schäffer, A. A., Zhang, J., Zhang, Z., Miller, W., and Lipman, D. L. 1997. Gapped BLAST and PSIBLAST: A new generation of protein database search programs. Nucleic Acids Res. 25:3389-3402.

Appel, R. D., Bairoch, A., and Hochstrasser, D. F. 1994. A new generation of information retrieval tools for biologists: The example of the 
ExPASy WWW server. Trends Biochem. Sci. 19:258-260.

Bauer, D. W. 1990. Molecular genetics of pathogenicity of Erwinia amylovora: Techniques, tools and their applications. Ph.D. thesis Cornell University, Ithaca, NY, U.S.A.

Bauer, D. W., and Beer, S. V. 1991. Further characterization of an hrp gene cluster of Erwinia amylovora. Mol. Plant-Microbe Interact. 4:493-499.

Beer, S. V., Bauer, D. W., Jiang, X. H., Laby, R. J., Sneath, B. J., Wei, Z.-M., Wilcox, D. A., and Zumoff, C. H. 1991. The hrp gene cluster of Erwinia amylovora. Pages 53-60 in: Advances in Molecular Genetics of Plant-Microbe Interactions, Vol. 1. H. Hennecke and D. P. S. Verma, eds. Kluwer Academic Publishers, Dordrecht, The Netherlands.

Bogdanove, A. J., Bauer, D. W., and Beer, S. V. 1998a. Erwinia amylovora secretes DspE, a pathogenicity factor and functional AvrE homolog, through the Hrp (type III secretion) pathway. J. Bacteriol. 180:2244-2247.

Bogdanove, A. J., Kim, J. F., Wei, Z., Kolchinsky, P., Charkowski, A. O., Conlin, A. K., Collmer, A., and Beer, S. V. 1998b. Homology and functional similarity of a $h r p$-linked pathogenicity operon, $d s p E F$, of Erwinia amylovora and the avrE locus of Pseudomonas syringae pathovar tomato. Proc. Natl. Acad. Sci. U.S.A. 95:1325-1330.

Bogdanove, A. J., Wei, Z.-M., Zhao, L., and Beer, S. V. 1996. Erwinia amylovora secretes harpin via a type III pathway and contains a homolog of yopN of Yersinia. J. Bacteriol. 178:1720-1730.

Eriksson, A. R. B., Andersson, R. A., Pirhonen, M., and Palva, E. T. 1998. Two-component regulators involved in the global control of virulence in Erwinia carotovora subsp. carotovora. Mol. PlantMicrobe Interact. 11:743-752.

Frederick, R. D., Majerczak, D. R., and Coplin, D. L. 1993. Erwinia stewartii WtsA, a positive regulator of pathogenicity gene expression, is similar to Pseudomonas syringae pv. phaseolicola $\mathrm{HrpS}$. Mol. Microbiol. 9:477-485.

Friedrich, M. J., and Kadner, R. J. 1987. Nucleotide sequence of the $u h p$ region of Escherichia coli. J. Bacteriol. 169:3556-3563.

Galán, J. E., and Bliska, J. B. 1996. Cross-talk between bacterial pathogens and their host cells. Annu. Rev. Cell. Dev. Biol. 12:221-255.

Gaudriault, S., Malandrin, L., Paulin, J.-P., and Barny, M.-A. 1997. DspA, an essential pathogenicity factor of Erwinia amylovora showing homology with AvrE of Pseudomonas syringae, is secreted via the Hrp secretion pathway in a DspB-dependent way. Mol. Microbiol. 26:1057-1069.

Goodman, R. N., and Novacky, A. J. 1994. The Hypersensitive Reaction in Plants to Pathogens: A Resistance Phenomenon. American Phytopathological Society, St. Paul, MN.

Grimm, C., Aufsatz, W., and Panopoulos, N. J. 1995. The hrpRS locus of Pseudomonas syringae pv. phaseolicola constitutes a complex regulatory unit. Mol. Microbiol. 15:155-165.

Hoch, J. A., and Silhavy, T. J. 1995. Two-component signal transduction. American Society for Microbiology, Washington, DC, U.S.A.

Hong, K. H., and Miller, V. L. 1998. Identification of a novel Salmonella invasion locus homologous to Shigella ipgDE. J. Bacteriol. 180:17931802

Huang, H.-C., Lin, R.-H., Chang, C.-J., Collmer, A., and Deng, W. L. 1995a. The complete hrp gene cluster of Pseudomonas syringae pv. syringae 61 includes two blocks of genes required for harpin $P_{s s}$ secretion that are arranged colinearly with Yersinia ysc homologs. Mol. Plant-Microbe Interact. 8:733-746.

Huang, J., Carney, B. F., Denny, T. P., Weissinger, A. K., and Schell, M. A. 1995b. A complex network regulates expression of eps and other virulence genes of Pseudomonas solanacearum. J. Bacteriol. 177:12591267.

Jefferson, R. A., Kavanagh, T. A., and Bevan, M. W. 1987. GUS fusions: Beta-glucuronidase as a sensitive and versatile gene fusion marker in higher plants. EMBO J. 6:3901-3907.

Jiang, J., Gu, B. H., Albright, L. M., and Nixon, B. T. 1989. Conservation between coding and regulatory elements of Rhizobium meliloti and Rhizobium leguminosarum dct genes. J. Bacteriol. 171:5244-5253.

Johnston, C., Peques, D. A., Hueck, C. J., Lee, C. A., and Miller, S. I. 1996. Transcriptional activation of Salmonella typhimurium invasion genes by a member of the phosphorylated response-regulator superfamily. Mol. Microbiol. 22:715-727.

Kay, S. A. 1997. PAS, present, and future: Clues to the origins of circadian clocks. Science 276:753-754

Kim, J. F., and Beer, S. V. 1998. HrpW of Erwinia amylovora, a new harpin that contains a domain homologous to pectate lyases of a distinct class. J. Bacteriol. 180:5203-5210.

Kim, J. F., Wei, Z.-M., and Beer, S. V. 1997. The $h r p A$ and $h r p C$ operons of Erwinia amylovora encode components of a type III pathway that secretes harpin. J. Bacteriol. 179:1690-1697.

Kunst, F., Debarbouille, M., Msadek, T., Young, M., Mauel, C., Karamata D., Klier, A., Rapoport, G., and Dedonder, R. 1988. Deduced polypeptides encoded by the Bacillus subtilis sacU locus share homology with two-component sensor-regulator systems. J. Bacteriol. 170:50935101.

Larsen, J. E. L., Gerdes, K., Light, J., and Molin, S. 1984. Low-copynumber plasmid-cloning vectors amplifiable by derepression of an inserted foreign promoter. Gene 28:45-54

Laville, J., Voisard, C., Keel, C., Maurhofer, M., Defago, G., and Haas, D. 1992. Global control in Pseudomonas fluorescens mediating antibiotic synthesis and suppression of black root rot of tobacco. Proc. Natl. Acad. Sci. U.S.A. 89:1562-1566.

Lonetto, M. A., Brown, K. L., Rudd, K. E., and Buttner, M. J. 1994 Analysis of the Streptomyces coelicolor sigE gene reveals the existence of a subfamily of eubacterial RNA polymerase $s$ factors in volved in the regulation of extracytoplasmic functions. Proc. Natl. Acad. Sci. U.S.A. 91:7573-7577.

Lukashin, A. V., and Borodovsky, M. 1998. GeneMark.hmm: New solution for gene finding. Nucleic Acids Res. 26:1107-1115.

Morett, E., and Segovia, L. 1993. The $\mathrm{s}^{54}$ bacterial enhancer-binding protein family: Mechanisms of action and phylogenetic relationship of their functional domains. J. Bacteriol. 175:6067-6074.

Nakayama, S.-I., and Watanabe, H. 1995. Involvement of cpxA, a sensor of a two-component regulatory system, in the $\mathrm{pH}$-dependent regulation of expression of Shigella sonnei virF gene. J. Bacteriol. 177:5062-5069.

Parkinson, J. S., and Kofoid, E. C. 1992. Communication modules in bacterial signaling proteins. Annu. Rev. Genet. 26:71-112.

Pegues, D. A., Hantmana, M. J., Behlau, I., and Miller, S. I. 1995 PhoP/PhoQ transcriptional repression of Salmonella typhimurium invasion genes: Evidence for a role in protein secretion. Mol. Microbiol. 17:169-181.

Rabin, R. S., and Stewart, V. 1993. Dual response regulators (NarL and NarP) interact with dual sensors (NarX and NarQ) to control nitrateand nitrite-regulated gene expression in Escherichia coli K-12. J. Bacteriol. 175:3259-3268.

Reese, M. G., and Eeckman, F. H. 1995. New neural network algorithms for improved eukaryotic promoter site recognition. Genome Sci. Tech. 1:45-46.

Ronson, C. W., Astwood, P. M., Nixon, B. T., and Ausubel, F. M. 1987. Deduced products of C4-dicarboxylate transport regulatory genes of Rhizobium leguminosarum are homologous to nitrogen regulatory gene products. Nucleic Acids Res. 15:7921-7934.

Sambrook, J., Fritsch, E. F., and Maniatis, T. A. 1989. Molecular Cloning: A Laboratory Manual. 2nd ed. Cold Spring Harbor Laboratory, Cold Spring Harbor, NY, U.S.A.

Sharma, S., Stark, T. F., Beattie, W. G., and Moses, R. E. 1986. Multiple control elements for the $u v r C$ gene unit of Escherichia coli. Nucleic Acids Res. 14:2301-2318.

Shingler, V. 1996. Signal sensing by s ${ }^{54}$-dependent regulators: Derepression as a control mechanism. Mol. Microbiol. 19:409-416.

Sneath, B. J., Howson, J. M., and Beer, S. V. 1990. A pathogenicity gene from Erwinia amylovora encodes a predicted protein product homologous to a family of procaryotic response regulators. (Abstr.) Phytopathology 80:1038.

Steinberger, E. M., and Beer, S. V. 1988. Creation and complementation of pathogenicity mutants of Erwinia amylovora. Mol. Plant-Microbe Interact. 1:135-144.

Stock, J. B., Ninfa, A. J., and Stock, A. M. 1989. Protein phosphorylation and regulation of adaptive response in bacteria. Microbiol. Rev. 53:450-490.

Tabor, S., and Richardson, C. C. 1985. A bacteriophage T7 DNA polymerase/promoter system for controlled exclusive expression of specific genes. Proc. Natl. Acad. Sci. U.S.A. 82:1074-1078.

van der Zwet, T., and Beer, S. V. 1999. Fire blight-Its nature, prevention and control: A practical guide to integrated disease management Agric. Information Bull. 681, U.S. Department of Agriculture, Washington, DC, U.S.A.

Wei, Z.-M., and Beer, S. V. 1993. HrpI of Erwinia amylovora functions in secretion of harpin and is a member of a new protein family. $\mathrm{J}$. 
Bacteriol. 175:7958-7967.

Wei, Z.-M., and Beer, S. V. 1995. hrpL activates Erwinia amylovora hrp gene transcription and is a member of the ECF subfamily of s factors. J. Bacteriol. 177:6201-6210.

Wei, Z.-M., Sneath, B. J., and Beer, S. V. 1992. Expression of Erwinia amylovora hrp genes in response to environmental stimuli. J. Bacteriol. 174:1875-1882.

Wengelnik, K., Van den Ackerveken, G., and Bonas, U. 1996. HrpG, a key hrp regulatory protein of Xanthomonas campestris pv. vesicatoria is homologous to two-component response regulators. Mol. PlantMicrobe Interact. 9:704-712.

Xiao, Y., Heu, S., Yi, J., Lu, Y., and Hutcheson, S. W. 1994. Identification of a putative alternate sigma factor and characterization of a mul- ticomponent regulatory cascade controlling the expression of Pseudomonas syringae pv. syringae Pss61 hrp and hrmA genes. J. Bacteriol. 176:1025-1036.

Xiao, Y., and Hutcheson, S. W. 1994. A single promoter sequence recognized by a newly identified alternate sigma factor directs expression of pathogenicity and host range determinants in Pseudomonas syringae. J. Bacteriol. 176:3089-3091.

Yuk, M. H., Harvill, E. T., and Miller, J. F. 1998. The BvgAS virulence control system regulates type III secretion in Bordetella bronchiseptica. Mol. Microbiol. 28:945-959.

Zhulin, I. B., Taylor, B. L., and Dixon, R. 1997. PAS domain S-boxes in Archaea, bacteria and sensors for oxygen and redox. Trends Biochem. Sci. 22:331-333. 